\title{
Pengaruh Tingkat Kepatuhan Wajib Pajak Terhadap Penerimaan Pajak Yang Dimoderasi Oleh Intensitas Pemeriksaan Pajak Pada Kantor Pelayanan Pajak Pratama Kuningan
}

\author{
Ida Soraya.,SE \\ Dadang Suhendar.,M.Si \\ Universitas Kuningan \\ (dadang.suhendar@ymail.com)
}

\begin{abstract}
The purpose of this study was to illustrate the level of taxpayer compliance, the tax audit intensity, and the tax revenue as well as the influence of taxpayer compliance and tax audit intensity either simultaneously or partially on tax revenue, and the influence of the tax audit intensity of the interaction level of taxpayer compliance on tax revenue in the Tax Office Primary Kuningan. The hypothesis that the authors propose was the level of taxpayer compliance and tax audit intensity simultaneously affect the tax revenue, the level of taxpayer compliance a positive effect on tax revenue, tax audit intensity positive effect on tax revenue, tax audit intensity positive effect on the interaction level of taxpayer compliance on tax revenue.

This research was conducted by using descriptive method verifikatif with quantitative approach. The study population was taxpayer compliance data, the realization of tax audits, and tax revenue to the Tax Office Primary Kuningan. Sampling using non probability sampling was purposive sampling technique in order to obtain samples of the data that taxpayer compliance, realization of tax audits, and tax revenue to the Tax Office Primary Kuningan for 5 years was from the year 2009 until the year 2013 in the form of data analysis tools description and analysis of statistical analysis through regression analysis moderating.

Based on the results of the descriptive analysis showed that the Tax Office Primary Kuningan generally have high levels of tax compliance, tax audit intensity, and tax revenues were likely to increase each semester with an average of 15583.50 respectively SPT, 16017.4010 tens of millions of dollars, and 59.8960 tens of millions of dollars. Statistical analysis showed that the level of taxpayer compliance and tax audit intensity simultaneously and significantly influential to tax revenues, the level of taxpayer compliance was significantly positive effect on the increase in tax revenue, tax audit intensity was significantly positive effect on tax revenue, and the tax audit intensity significantly positive effect on the interaction level of taxpayer compliance on tax revenues.

Keywords: Level of Taxpayer Compliance, Tax Audit Intensity, and Tax Revenue.
\end{abstract}

\section{PENDAHULUAN}

\section{Latar Belakang Masalah}

Pajak merupakan salah satu sumber yang cukup penting bagi penerimaan negara guna pembiayaan pembangunan. Kontribusi pajak terhadap pembangunan telah menyamakan atau bahkan lebih besar dari sektor minyak dan gas sebagai 
sumber dana pembangunan. Saat ini Indonesia mulai memprioritaskan sektor pajak dari sisi regulasinya sebagai sumber pendanaan pembangunan berbagai bidang, misalnya pembangunan dalam bidang ekonomi, sosial dan budaya sebagaimana tercantum dalam undang-undang. Dalam pembangunan ini tidak akan tercapai apabila tidak ada kerjasama antar pemerintah dengan masyarakat, dalam hal ini masyarakat mempunyai peranan penting untuk ikut serta dalam menjalankan fungsi pemerintahan salah satu caranya yaitu dengan membayar pajak.

Pemerintah selalu berupaya untuk meningkatkan tax ratio secara bertahap dengan memperhatikan kondisi ekonomi Indonesia dan ekonomi dunia. Peningkatan secara bertahap tax ratio dilakukan melalui penyempurnaan terhadap kebijakan dan administrasi perpajakan, sehingga basis pajak dapat semakin luas, dan potensi pajak yang ada dapat dipungut secara optimal. Langkah-langkah strategis telah beberapa kali ditempuh oleh pemerintah yang ditandai dengan beberapa kali perubahan undangundang perpajakan yang cukup signifikan. Peubahan yang pertama terjadi tahun 1983, kemudian dilakukan perubahan kedua pada tahun 1994, diikuti perubahan ketiga yang dilakukan pada tahun 2000 berupa penurunan lapisan kena pajak penghasilan badan (Undang-undang No.17 Tahun 2000 Pasal 17) dan pertengahan 2008 pemerintah kembali mengadakan perubahan dan mengesahkan Undang-undang No.36 Tahun 2008 sebagai perubahan keempat tentang pajak penghasilan, dan baru-baru ini pemerintah mengeluarkan Peraturan Pemerintah
No.46 Tahun 2013 tentang Ketentuan Pajak Penghasilan, merupakan kebijakan pemerintah yang mengatur mengenai pajak penghasilan atas penghasilan dari usaha yang diterima atau diperoleh wajib pajak yang memiliki peredaran bruto tertentu.

Kontribusi penerimaan pajak terhadap penerimaan negara diharapkan semakin meningkat dari tahun ke tahun, seiring dengan semakin menurunnya peranan minyak dan gas bumi terhadap penerimaan negara. Dibawah ini adalah data tentang penerimaan pajak yang telah dihimpun oleh Badan Pusat Statistik Republik Indonesia.

Dilihat dari sumbernya, penerimaan perpajakan terdiri dari pajak dalam negeri dan pajak perdagangan internasional. Dalam Nota Keuangan dan Anggaran Pendapatan Dan Belanja Negara Tahun Anggaran 2013, pada periode 2007-2012 kontribusi pajak yang terdiri atas penerimaan pajak dalam negeri dan pajak perdangangan internasional dengan kontribusi ratarata masing-masing sebesar $95.4 \%$ per tahun dan $4.6 \%$ per tahun, meningkat rata-rata $15.5 \%$ per tahun pada periode 2007-2011 penerimaan pajak dalam negeri dalam periode tersebut meningkat rata-rata sebesar $14.9 \%$ per tahun, sedangkan penerimaan pajak perdagangan internasional meningkat rata-rata sebesar $26.8 \%$ per tahun.

Dilihat dari proporsinya terhadap Produk Domestik Bruto (tax ratio), kontribusi penerimaan perpajakan menurun dari $12.4 \%$ pada tahun 2007 menjadi $12.3 \%$ pada tahun 2012. Hal ini menandakan tax ratio Indonesia masih rendah.

Direktorat Jenderal Pajak 
(Ditjen Pajak) mencatat, rasio pajak di Indonesia masih sangat rendah, terutama dibandingkan dengan negara lain dalam satu kawasan. Tax ratio rendah karena sangat ditentukan oleh struktur perekonomian. Upaya yang dilakukan oleh Direktorat Jenderal Pajak (DJP) dalam mencapai target penerimaan pajak yang diharapkan belum sepenuhnya memuaskan. Hal ini terlihat dari jumlah penerimaan pajak dalam beberapa tahun terakhir, walaupun tejadi peningkatan penerimaan pajak, tetapi masih jauh dari target penerimaan pajak yang diharapkan. Kebijakan administrasi perpajakan yang dilakukan oleh Direktorat Jenderal Pajak (DJP) terutama terhadap pemenuhan pengertian dan kesadaran para wajib pajak ternyata masih kurang sehingga target penerimaan pajak yang ditetapkan kurang tercapai secara maksimal.

Sebagaimana hasil observasi penulis pada Kantor Pelayanan Pajak Pratama Kabupaten Kuningan menunjukkan bahwa penerimaan pajak di Kabupaten Kuningan cenderung tidak stabil. Berikut disajikan tabel yang menjelaskan tentang penerimaan pajak di Kabupaten Kuningan dari tahun 2011 hingga 2013.

Dilihat dari tabel di atas dapat dlihat bahwa selama tiga tahun terakhir, yaitu tahun 2011 hingga 2013, kondisi penerimaan di KPP Pratama Kuningan cenderung tidak stabil yaitu sempat mengalami kenaikan dari tahun 2011 ke tahun 2012 sebesar 122,20\% melebihi dari target yang ditentukan yaitu sebesar $100 \%$ dan kembali mengalami penuruna pada tahun 2013 yaitu sebesar 96,20\% dari target yang ditentukan sebesar 100\%. Demikian pula dengan tingkat kepatuhan wajib pajaknya yang mengalami penurunan yaitu pada tahun 2011 ke 2012 sebesar $35,04 \%$ dari target $67,5 \%$. Penurunan tingkat kepatuhan dapat disebabkan oleh masih rendahnya pengetahuan wajib pajak mengenai perpajakan karena kurangnya informasi yang diperoleh. Hal ini bertolak belakang dengan harapan KPP Pratama Kuningan yang menginginkan adanya penerimaan dan kepatuhan wajib pajak tinggi setiap tahunnya dan mampu mencapai target yang telah ditentukan.

Tentu pemerintah berupaya meningkatkan penerimaan perpajakan dengan tidak mengganggu pertumbuhan ekonomi dan iklim investasi serta dunia usaha. Upaya tersebut ditempuh antara lain dengan: i) meningkatkan perbaikan penggalian potensi perpajakan; ii) melakukan perbaikan kualitas pemeriksaan dan penyidikan pajak; iii) menyempurnakan sistem informasi teknologi; iv) melakukan perbaikan kebijakan perpajakan nasional yang diarahkan bagi perluasan basis pajak; v) meningkatkan kegiatan sensus pajak nasional; vi) meningkatkan pengawasan dan pelayanan di bidang kepabeanan dan cukai; vii) meningkatkan pengawasan dan pelayanan di bidang kepabeanan dan cukai; viii) ekstensifikasi cukai; ix) menyesuaikan tarif PPnBM atas kelompok Barang Kena Pajak (BKP) yang tergolong mewah selain kendaraan bermotor; dan $\mathrm{x}$ ) pemberian insentif fiskal bagi kegiatan ekonomi strategis.

Namun demikian, upaya pemerintah untuk mengoptimalkan pendapatan negara tidak akan berjalan tanpa dukungan dari 
berbagai pihak. Koordinasi antar Kementerian/Lembaga terkait penerimaan negara juga sangat penting, mengingat upaya peningkatan pendapatan negara bukan hanya menjadi tugas Kementerian Keuangan saja. Selain itu, kesadaran masyarakat untuk patuh dan taat membayar pajak juga hal yang penting. Tanpa kesadaran masyarakat yang tinggi khususnya dalam membayar pajak, upaya optimalisasi pendapatan negara tidak akan mudah tercapai.

Kepatuhan merupakan pemicu keadaan motivasional yang kuat pada individu-individu dan kepatuhan menjadi elemen dasar yang penting bagi pembentukan kehidupan sosial yang tertib dan teratur. Isu kepatuhan menjadi penting karena ketidakpatuhan secara bersamaan akan menimbulkan upaya menghindarkan pajak yang mengakibatkan berkurangnya penyetoran dana pajak ke kas negara. Wajib pajak dikategorikan sebagai wajib pajak patuh apabila wajib pajak tersebut melaksanakan pemenuhan kewajiban pajak sesuai perundang-undangan pajak, berlaku mulai dari menghitung, memotong, menyetorkan sampai dengan melaporkan kewajiban pajaknya. Kepatuhan membayar pajak itu sendiri khususnya dalam hal penyampaian laporan dan pengisian SPT.

Pemeriksaan pajak juga perlu dilakukan karena tujuan dari pemeriksaan pajak adalah untuk menguji kepatuhan pemenuhan kewajiban perpajakan dalam rangka memberikan kepastian hukum, keadilan, dan pembinaan kepada Wajib

Pajak dan untuk tujuan lain dalam rangka melaksanakan ketentuan peraturan perundangundangan perpajakan tercantum dalam Keputusan Menteri Keuangan No.545/KMK.04/2000.

Berdasarkan latar belakang masalah tersebut maka penulis tertarik untuk melakukan penelitian mengenai pengaruh tingkat kepatuhan wajib pajak terhadap penerimaan pajak yang dimoderasi oleh intensitas pemeriksaan pajak pada Kantor Pelayanan Pajak Pratama Kabupaten Kuningan.

\section{Rumusan Masalah}

Dari latar belakang masalah yang dikemukaan di atas, maka yang menjadi rumusan masalah dalam penelitian ini adalah:

1. Bagaimana gambaran tingkat kepatuhan wajib pajak, intensitas pemeriksaan wajib pajak, dan penerimaan pajak pada Kantor Pelayanan Pajak Pratama Kuningan?

2. Bagaimana pengaruh tingkat kepatuhan wajib pajak dan intensitas pemeriksaan pajak terhadap penerimaan pajak pada Kantor Pelayanan Pajak Pratama Kuningan?

3. Bagaimana pengaruh tingkat kepatuhan wajib pajak terhadap penerimaan pajak pada Kantor Pelayanan Pajak Pratama Kuningan?

4. Bagaimana pengaruh intensitas pemeriksaan pajak terhadap penerimaan pajak pada Kantor Pelayanan Pajak Pratama Kuningan?

5. Bagaimana pengaruh intensitas pemeriksaan pajak terhadap interaksi tingkat kepatuhan wajib pajak terhadap penerimaan pajak pada Kantor Pelayanan Pajak Pratama Kuningan? 


\section{TINJAUAN PUSTAKA}

Ditinjau dari jumlah pendapatan yang diterima oleh negara, penerimaan pajak merupakan penerimaan yang dominan dari seluruh penerimaan negara. Banyak para ahli memberikan batasan tentang pajak, tetapi pada intinya mempunyai maksud dan tujuan yang sama. Pengertian pajak berdasarkan Pasal 1 UU No. 28 Tahun 2007 tentang Ketentuan Umum dan Tata Cara Perpajakan adalah: "Pajak adalah kontribusi wajib pada negara yang terutang oleh orang pribadi atau badan yang bersifat memaksa berdasarkan undang-undang, dengan tidak mendapatkan imbalan secara langsung dan digunakan untuk keperluan negara bagi sebesarbesarnya kemakmuran rakyat".

\section{Kepatuhan Wajib Pajak}

Menurut Deviano dan Rahayu (2006:110) mengatakan bahwa: "Kepatuhan perpajakan dapat didefinisikan sebagai suatu keadaan dimana wajib pajak memenuhi semua kewajiban perpajakan dan melaksanakan hak perpajakan". Ada terdapat 2 macam kepatuhan yaitu kepatuhan formal dan kepatuhan material.

$$
\text { 1. Kepatuhan formal, }
$$
adalah suatu keadaan dimana wajib pajak memenuhi kewajiban secara formal sesuai dengan ketentuan dalam undang-undang perpajakan.

2. Kepatuhan material, adalah suatu keadaan dimana wajib pajak secara substantif atau hakikatnya memenuhi semua ketentuan material perpajakan. Kepatuhan material dapat juga meliputi kepatuhan formal.

Dapat disimpulkan juga kepatuhan formal adalah kepatuhan yang dapat dilihat dari penyampaian SPT dan pembayaran pajak yang terutang sudah sesuai jangka waktu yang ditentukan. Sedangkan kepatuhan material adalah kepatuhan yang dapat dilihat dari pemenuhan kewajibannya sendiri (pajak penghasilan 25 atau pajak penghailan 29) maupun pajak yang dipotong atau dipungut dari pihak lain (pajak penghasilan 21, 22, dan 23).

Indikator yang digunakan dalam penelitian ini mengenai kepatuhan wajib pajak menggunakan dasar pemikiran dari penjelasan menurut Rahayu (2010:139) yang mengatakan bahwa: "Kepatuhan material dapat meliputi kepatuhan formal. Wajib pajak yang memenuhi kepatuhan material adalah wajib pajak yang mengisi dengan jujur, lengkap, dan benar Surat Pemberitahuan (SPT) sesuai ketentuan dan menyampaikannya ke KPP sebelum batas waktu berakhir". Dari hasil pemikiran di atas, maka indikator untuk kepatuhan wajib pajak adalah diukur berdasarkan jumlah penyampaian Surat Pemberitahuan (SPT) yang dilaporkan oleh Wajib Pajak Badan KPP Pratama Kuningan.

\section{Intensitas Pemeriksaan Pajak}

Pengertian pemeriksaan menurut Undang-undang Nomor 28 Tahun 2007 adalah: "Serangkaian kegiatan menghimpun dan mengolah data, keterangan dan/atau bukti yang dilaksanakan secara objektif dan profesional berdasarkan suatu standar pemeriksaan untuk menguji kepatuhan pemenuhan kewajiban

perpajakan dan/atau untuk
tujuan lain dalam rangka
melaksanakan ketentuan peraturan
perundang-undangan perpajakan".
Pemeriksaan pajak dapat


memberikan pengaruh yang baik tehadap kepatuhan wajib pajak dalam membayar pajak, yaitu dapat menghindari terjadinya penipuan pajak oleh wajib pajak yang diperiksa. Kepatuhan wajib pajak salah satunya dapat dilihat dari peningkatan jumlah penerimaan pajak yang diterima oleh negara. Dari hasil pemikiran tersebut, maka indikator pemeriksaan pajak diukur berdasarkan jumlah realisasi pemeriksaan pada KPP Pratama Kuningan.

\section{Penerimaan Pajak}

Menurut Waluyo dan Ilyas (2010:2) menjelaskan bahwa: "Pajak adalah iuran kepada negara (yang dapat dipaksakan) yang terutang oleh yang wajib membayarnya menurut peraturan-peraturan, dengan tidak mendapat prestasi kembali, yang langsung dapat ditunjuk dan yang gunanya adalah untuk

membiayai pengeluaranpengeluaran umum berhubungan dengan tugas negara yang menyelenggarakan pemerintahan". Pentingnya peran perpajakan dalam

APBN membutuhkan proyeksi penerimaan perpajakan yang credible agar target akurat dan dapat dicapai. Tepat tidaknya perencanaan besaran penerimaan perpajakan (target penerimaan perpajakan) akan berpengaruh pada kelancaran pelaksanaan pembangunan nasional. Meskipun terdapat tujuan untuk mningkatkan penerimaan perpajakan maupun tax ratio secara signifikan, penetapan target penerimaan perpajakan tidak boleh melebihi kemampuan dari perekonomian Indonesia itu sendiri. Oleh karena itu, dalam menetapkan target penerimaan perpajakan harus memperhatikan potensi yang ada serta berbagai faktor perubahan indikator ekonomi yang sedang terjadi maupun perubahan kebijakan (policy) dan administrasi. Dari hasil pemikiran di atas, maka indikator pemeriksaan pajak diukur berdasarkan jumlah realisasi penerimaan pajak pada KPP Pratama Kuningan.

\section{Hubungan Kepatuhan Wajib Pajak dengan Penerimaan Pajak}

Hubungan antara kepatuhan wajib pajak dan penerimaan pajak dalam penelitian ini berdasarkan dari pernyataan menurut Ismawan (2001:11) yang menjelaskan bahwa: "Permasalahan tax compliance ini menjadi penting artinya karena apabila tidak ada kepatuhan atau compliance maka akan menimbulkan tindakan penghindaran, penyelundupan dan pelalaian pajak yanga pada akhirnya akan berimbas pada penurunan penerimaan pajak negara". Menurut Widodo

(2010:67) juga menjelaskan hubungan antara kepatuhan wajib pajak dengan penerimaan pajak yaitu: "Jika angka kepatuhan pajak rendah, maka secara

otomatis akan berdampak pada rendahnya penerimaan pajak sehingga menurunkan tingkat penerimaan APBN pula". Selanjutnya menurut John Hutagaol, Wing Wahyu Winarno, dan Arya Pradipta (2007) juga mengungkapkan

mengenai keterkaitan antara kepatuhan pajak dengan penerimaan pajak bahwa: "Kepatuhan wajib pajak berpengaruh atas penerimaan dari sektor pajak".

\section{Hubungan Intensitas Pemeriksaan Pajak dengan Kepatuhan Material Wajib Pajak}

Keterkaitan

pemeriksaan pajak dengan 
kepatuhan Wajib Pajak dalam penelitian ini berdasarkan dari pernyataan Rahayu (2010: 246) yang menjelaskan bahwa: "Tujuan yang terutama dari pemeriksaan adalah pengujian kepatuhan wajib pajak dalam memenuhi kewajiban perpajakan, kewajiban-kewajiban perpajakan yang harus dipenuhi oleh wajib pajak, termasuk di dalamnya tidak terkecuali adalah kewajiban para pemungut dan pemotong pajak". Ditambahkan juga dari pernyatan menurut Gunadi (2005) yang mengungkapkan bahwa: "Tax compliance merupakan salah satu indikator penting dalam mengukur

kinerja administrasi perpajakan oleh institusi pemungut pajak. Salah satu sarana (tools) dalam peningkatan kepatuhan wajib pajak adalah pemeriksaan".

\section{Hipotesis}

Berdasarkan latar belakang masalah, kajian teoritis, perumusan masalah dan paradigm penelitian di atas maka dalam penelitian ini dapat di-rumuskan hipotesis terhadap permasalahan tersebut sebagai berikut:

$\mathrm{H}_{1}$ : Tingkat kepatuhan wajib pajak dan intensitas pemeriksaan pajak berpengaruh secara simultan terhadap penerimaan pajak.

$\mathrm{H}_{2}$ : Tingkat kepatuhan wajib pajak berpengaruh positif terhadap penerimaan pajak.

$\mathrm{H}_{3}$ : Intensitas pemeriksaan pajak berpengaruh positif terhadap penerimaan pajak.

$\mathrm{H}_{4}$ : Intensitas pemeriksaan pajak berpengaruh positif terhadap interaksi tingkat kepatuhan wajib pajak terhadap penerimaan pajak.

\section{METODE PENELITIAN}

Metode Penelitian yang Digunakan

Metode penelitian yang digunakan dalam penelitian ini adalah metode penelitian deskriptif verifikatif dengan pendekatan kuantitatif yaitu menjelaskan, mendeskripsikan masing-masing variabel dengan menggunakan data berupa angka kemudian menjelaskan hubungan kedua variabel melalui uji hipotesis.

\section{Operasional Variabel}

Variabel yang terdapat dalam penelitian ini terdiri atas variabel independen $(\mathrm{X})$ yaitu tingkat kepatuhan wajib pajak, variabel moderating ( $Z$ ) yaitu intensitas pemeriksaan pajak, dan variabel dependen (Y) yaitu penerimaan pajak.

\section{Data dan Sumber Data}

Data yang digunakan dalam penelitian ini adalah data sekunder berupa data kepatuhan wajib pajak, realisasi pemeriksaan pajak, dan realisasi penerimaan pajak pada Kantor Pelayanan Pajak Pratama Kuningan. Sumber data dari objek penelitian yaitu Kantor Pelayanan Pajak Pratama Kuningan

\section{Teknik Pengumpulan Data}

Untuk memperoleh informasi dan data yang akan diolah dalam penelitian ini, maka pengumpulan data dilakukan dengan cara yaitu:

1. Penelitian kepustakaan (library research), penelitian yang dilakukan dengan cara membacadan mempelajari literatur-literatur yang berkaitan dengan topic yang dipilih.

2. Untuk memperoleh data maka penulis mengadakan penelitian ke Kantor Pelayanan Pajak Pratama yang dilakukan dengan cara 
observasi dan dokumentasi.

\section{Populasi dan Sampel}

Dalam penelitian ini yang menjadi populasi penelitian adalah data kepatuhan wajib pajak, realisasi pemeriksaan pajak, dan realisasi penerimaan pajak pada Kantor Pelayanan Pajak Pratama Kuningan. Sampling dapat diartikan sebagai suatu cara untuk mengumpulkan data atau pengambilan sampel yang sifatnya tidak menyeluruh, yaitu tidak mencakup seluruh populasi penelitian tetapi hanya sebagian dari populasi itu saja.

Teknik sampel yang digunakan dalam penelitian ini adalah sampling purposive. Sugiyono (2010:85) menyatakan bahwa: "Sampling purvosive adalah teknik penentuan sampel dengan pertimbangan tertentu". Adapun yang menjadi pertimbangan diambilnya tahun 2009 sampai dengan tahun 2013 adalah karena pada periode tersebut jumlah realisasi pemeriksaan pajak cenderung naik tetapi mengalami penurunan yang cukup drastis pada tahun 2012.

Analisis diskriptif digunakan oleh peneliti untuk memberikan informasi mengenai karakteristik variabel penelitian yang utama dan daftar demografi responden. Menurut Ghozali (2011:19) menjelaskan bahwa: "Analisis deskriptif memberikan gambaran atau deskripsi suatu data yang dilihat rata-rata (mean), standar deviasi, varian, maksimum, minimum, sum, range, kurtosis dan skewness (kemencengan distribusi)".

\section{Analisis Statistik}

Analisis statistik merupakan analisis data yang diperlukan untuk melakukan pengujian hipotesis penelitian. Dimana dalam penelitian ini analisis statistik dilakukan melalui beberapa uji statistik sebagai berikut:

a. Uji Asumsi Klasik

Untuk melakukan uji asumsi klasik atas data penelitian ini, maka peneliti melakukan uji normalitas, uji multikolonieritas, uji autokorelasi dan uji heteroskedastisitas.

b. Analisis Regresi Moderating

Analisis regresi moderating digunakan untuk menganalisa pengaruh variabel bebas terhadap variabel tidak bebas dengan adanya variabel moderating. Analisis ini digunakan untuk mengetahui pengaruh tingkat kepatuhan wajib pajak terhadap penerimaan pajak yang dimoderasi oleh intensitas pemeriksaan pajak.

\section{HASIL PENELITIAN DAN PEMBAHASAN}

\section{Tingkat Kepatuhan Wajib Pajak di KPP Pratama Kuningan}

Tingkat kepatuhan wajib pajak di KPP Pratama Kuningan secara umum menunjukkan kecenderungan meningkat setiap semesternya dengan rata-rata sebesar 15583,50 dimana nilai minimum sebesar 10358 terjadi pada semester 1 tahun 2009 dan nilai maksimum sebesar 21584 terjadi pada semester 2 tahun 2013. Adanya peningkatan tersebut dapat diakibatkan oleh semakin banyaknya wajib pajak yang sadar akan kewajibannya membayar pajak. Selain itu, adanya pelayanan yang baik serta prosedur yang sederhana dan mudah mendorong masyarakat untuk membayar pajak tepat waktu.

\section{Intensitas Pemeriksaan Pajak di KPP Pratama Kuningan}

Intensitas pemeriksaan pajak 
di KPP Pratama Kuningan secara umum menunjukkan kecenderungan meningkat setiap semesternya dengan rata-rata sebesar 59,8960 dimana nilai minimum sebesar 6,17 terjadi pada semester 1 tahun 2012 dan nilai maksimum sebesar 122,30 terjadi pada semester 2 tahun 2011. Adanya kenaikan tersebut dapat diakibatkan oleh meningkatnya pemantauan dan verifikasi dari pihak KPP Pratama Kuningan sehingga pembayaran pajak yang kurang dapat diperiksa dengan baik. Selain hal tersebut, meningkatnya kualitas SDM para petugas pajak mampu menunjang terhadap peningkatan intensitas pemeriksaan pajak.

\section{Penerimaan Pajak di KPP Pratama Kuningan}

Penerimaan pajak di KPP Pratama Kuningan secara umum menunjukkan kecenderungan meningkat setiap semesternya dengan rata-rata sebesar 16017,4010 dimana nilai minimum sebesar 10292,61 terjadi pada semester 1 tahun 2009 dan nilai maksimum sebesar 23704,54 terjadi pada semester 2 tahun 2013. Adanya kenaikan tersebut seiring dengan peningkatan tingkat kepatuhan wajib pajak sehingga penerimaan pajak setiap semesternya mengalami kecenderungan meningkat. Selain itu, adanya peningkatan kinerja dan kualitas SDM petugas pajak menunjang terhadap penerimaan pajak yang lebih maksimal setiap semestarnya.

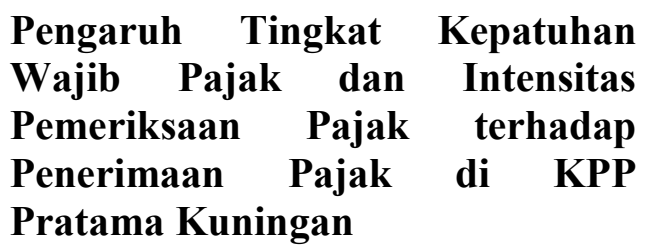

Analisis koefisien determinasi menunjukkan pengaruh tingkat kepatuhan wajib pajak, intensitas pemeriksaan pajak, dan moderating (interaksi antara tingkat kepatuhan wajib pajak dengan intensitas pemeriksaan pajak) secara simultan terhadap penerimaan pajak adalah sebesar $94,0 \%$ dan sisanya sebesar $6,0 \%$ dipengaruhi oleh faktor lain di luar model regresi. Hasil uji simultan diperoleh nilai Fhitung $=15,211>$ $\mathrm{F}_{\text {tabel }}=4,757$ maka Ho ditolak dan $\mathrm{Ha}$ diterima artinya tingkat kepatuhan wajib pajak dan intensitas pemeriksaan pajak berpengaruh secara simultan terhadap penerimaan pajak. Nilai signifikansi sebesar $0,003<0,05$ menunjukkan adanya pengaruh tingkat kepatuhan wajib pajak dan intensitas pemeriksaan pajak secara simultan terhadap penerimaan pajak adalah signifikan pada taraf signifikansi 5\%.

Hasil penelitian tersebut menunjukkan bahwa tingkat kepatuhan wajib pajak dan intensitas pemeriksaan pajak memiliki hubungan dengan penerimaan

pajak. Menurut Widodo (2010:67) menjelaskan hubungan antara tingkat kepatuhan wajib pajak dengan penerimaan pajak yaitu: "Jika angka kepatuhan

pajak rendah, maka secara otomatis akan berdampak pada rendahnya penerimaan pajak sehingga menurunkan tingkat penerimaan APBN pula". Sedangkan

keterkaitan antara intensitas pemeriksaan pajak dengan tingkat kepatuhan wajib pajak dalam penelitian ini berdasarkan dari pernyataan Rahayu (2010:246) yang menjelaskan tujuan yang terutama dari pemeriksaan adalah: "Pengujian tingkat kepatuhan wajib pajak dalam memenuhi kewajiban perpajakan, 
kewajiban-kewajiban perpajakan yang harus dipenuhi oleh wajib pajak, termasuk di dalamnya tidak terkecuali adalah kewajiban para pemungut dan pemotong pajak".

\section{Pengaruh Tingkat Kepatuhan Wajib Pajak terhadap Penerimaan Pajak di KPP Pratama Kuningan}

Analisis regresi moderating diperoleh koefisien regresi variabel tingkat kepatuhan wajib pajak sebesar 0,695 menunjukkan bahwa apabila tingkat kepatuhan wajib pajak mengalami kenaikan sebesar 1 lembar maka penerimaan pajak akan mengalami peningkatan sebesar 0,695 rupiah. Koefisien regresi variabel tingkat kepatuhan wajib pajak bernilai positif artinya terjadi pengaruh positif antara tingkat kepatuhan wajib pajak terhadap penerimaan pajak, semakin meningkat tingkat kepatuhan wajib pajak maka semakin tinggi pula penerimaan pajak dan begitu pula sebaliknya.

Selanjutnya menurut Widodo (2010:67) juga menjelaskan hubungan antara tingkat kepatuhan wajib pajak dengan penerimaan pajak yaitu: "Jika angka kepatuhan pajak rendah, maka secara otomatis akan berdampak pada rendahnya penerimaan pajak sehingga menurunkan tingkat penerimaan APBN pula". Sedangkan menurut Hutagaol, Winarno, dan Pradipta (2007) juga

mengungkapkan mengenai keterkaitan antara kepatuhan pajak dengan penerimaan pajak sebagai berikut: "Tingkat kepatuhan wajib pajak berpengaruh atas

penerimaan dari sektor pajak".

\begin{tabular}{|c|c|}
\hline engaruh & \\
\hline $\begin{array}{l}\text { emeriksaan } \\
\text { enerimaan }\end{array}$ & $\begin{array}{l}\text { Pajak } \\
\text { Pajak }\end{array}$ \\
\hline
\end{tabular}

Pengujian hipotesis diperoleh nilai thitung $=3,863>$ tabel $=1,943$ maka Ho ditolak dan $\mathrm{Ha}$ diterima artinya tingkat kepatuhan wajib pajak berpengaruh positif terhadap peningkatan penerimaan pajak. Nilai signifikansi sebesar $0,008<0,05$ maka adanya pengaruh positif antara tingkat kepatuhan wajib pajak terhadap peningkatan penerimaan pajak adalah signifikan pada taraf signifikansi 5\%. Hasil penelitian tersebut sesuai dengan teori yang disampaikan oleh Ismawan (2001:11) yang menjelaskan bahwa: "Permasalahan tax compliance ini menjadi penting artinya karena apabila tidak ada kepatuhan atau compliance maka akan menimbulkan tindakan penghindaran, penyelundupan dan pelalaian pajak yang pada akhirnya akan berimbas pada penurunan penerimaan pajak negara".

\section{Pratama Kuningan}

Analisis regresi moderating diperoleh koefisien regresi variabel intensitas pemeriksaan pajak sebesar 78,570 menunjukkan bahwa apabila intensitas pemeriksaan pajak mengalami kenaikan sebesar 1 satuan maka penerimaan pajak akan mengalami peningkatan sebesar 78,570 rupiah. Koefisien regresi variabel intensitas pemeriksaan pajak bernilai positif artinya terjadi pengaruh positif antara intensitas pemeriksaan pajak terhadap penerimaan pajak, semakin meningkat intensitas pemeriksaan pajak maka semakin tinggi pula penerimaan pajak dan begitu pula sebaliknya. Pengujian hipotesis diperoleh nilai thitung $=3,425>$ tabel $=$ 1,943 maka Ho ditolak dan $\mathrm{Ha}$ diterima artinya intensitas 
pemeriksaan pajak berpengaruh positif terhadap penerimaan pajak. Nilai signifikansi sebesar 0,014< 0,05 maka adanya pengaruh positif antara intensitas pemeriksaan pajak terhadap peningkatan penerimaan pajak adalah signifikan pada taraf signifikansi 5\%.

Hasil penelitian tersebut menunjukkan bahwa intensitas pemeriksaan pajak memiliki hubungan dengan penerimaan pajak. Keterkaitan antara pemeriksaan

pajak dan penerimaan pajak dalam penelitian ini didasarkan pada pernyataan menurut Salip dan Wato (2006) yang mengungkapkan bahwa: "Hasil pemeriksaan pajak secara nominal telah meningkatkan penerimaan pajak". Begitu pula dengan

pernyataan menurut

Wonglimpiyarat (2010) yang mengungkapkan keterkaitan pemeriksaan pajak dan penerimaan pajak bahwa: "The findings reveal that tax

auditing would provide high quality audits to the financial reporting process for statutory purposes, enhance the state's ability to collect tax and improve performance of the tax ystem".

\section{Pengaruh Intensitas Pemeriksaan Pajak terhadap Interaksi Tingkat Kepatuhan Wajib Pajak terhadap Penerimaan Pajak di KPP Pratama Kuningan}

Analisis regresi moderating diperoleh koefisien regresi variabel moderating sebesar 0,007 menunjukkan bahwa apabila moderating (interaksi antara tingkat kepatuhan wajib pajak dengan intensitas pemeriksaan pajak) mengalami kenaikan sebesar 1 satuan maka penerimaan pajak akan mengalami peningkatan sebesar
0,007. Koefisien regresi moderat bernilai positif artinya terjadi pengaruh positif antara tingkat kepatuhan wajib pajak terhadap penerimaan pajak yang dimoderasi oleh intensitas pemeriksaan pajak, semakin meningkat moderating (interaksi antara tingkat kepatuhan wajib pajak dengan intensitas pemeriksaan pajak) maka semakin meningkat pula penerimaan pajak.

Pengujian hipotesis diperoleh nilai thitung $=5,115>$ tabel $=1,943$ maka Ho ditolak dan $\mathrm{Ha}$ diterima artinya intensitas pemeriksaan pajak berpengaruh positif terhadap interaksi tingkat kepatuhan wajib pajak terhadap penerimaan pajak. Nilai signifikansi sebesar $0,002<$ 0,05 maka intensitas pemeriksaan pajak berpengaruh positif terhadap interaksi tingkat kepatuhan wajib pajak terhadap penerimaan pajak adalah signifikan pada taraf signifikansi $5 \%$. Hal ini menunjukkan bahwa variabel intensitas pemeriksaan pajak dapat dinyatakan sebagai variable moderating.

Menurut Gunadi (2005) mengungkapkan bahwa: "Tax Compliance merupakan salah satu indikator penting dalam mengukur kinerja administrasi perpajakan oleh institusi pemungut pajak. Salah satu sarana (tools) dalam peningkatan tingkat kepatuhan wajib pajak adalah pemeriksaan". Pemeriksaan pajak dilakukan sebagai upaya penegakan hukum pajak yang diperlukan tenaga pemeriksa pajak dalam kuantitas dan kualitas yang memadai. Untuk mendapatkan jaminan mutu atas hasil kerja pemeriksaan selain diperlukan kuantitas dan kualitas yang memadai diperlukan juga prosedur pemeriksaan, serta norma 
dan kaidah yang mengatur seorang pemeriksa pajak. Pemeriksaan pajak juga perlu dilakukan karena tujuan dari pemeriksaan pajak adalah untuk menguji kepatuhan pemenuhan kewajiban perpajakan dalam rangka memberikan kepastian hukum, keadilan, dan pembinaan kepada wajib pajak dan untuk tujuan lain dalam rangka melaksanakan ketentuan peraturan perundangundangan perpajakan tercantum dalam Keputusan Menteri Keuangan No.545/KMK.04/2000.

Kepatuhan merupakan pemicu keadaan motivasional yang kuat pada individu-individu dan kepatuhan menjadi elemen dasar yang penting bagi pembentukan kehidupan sosial yang tertib dan teratur. Isu kepatuhan menjadi penting karena ketidakpatuhan secara bersamaan akan menimbulkan upaya menghindarkan pajak yang mengakibatkan berkurangnya penyetoran dana pajak ke kas negara. Wajib pajak patuh merupakan wajib pajak yang taat dalam pembayaran pajak, dan dalam mengisi Surat Pemberitahuan (SPT) dilakukan dengan benar, lengkap, dan jelas, sehingga tidak perlu dilakukan penelitian dan pemeriksaan, tentunya dengan penekanan penerimaan pajak sebagai kontribusi terbesar penerimaan Negara diharapkan semua wajib pajak di Indonesia berpredikat patuh, yang akan berimplikasi pada optimalisasi penerimaan pajak.

\section{KESIMPULAN DAN SARAN Kesimpulan}

Berdasarkan hasil penelitian dan pembahasan yang telah diuraikan pada bab sebelumnya, maka penulis dapat menarik beberapa kesimpulan sebagai berikut:

1. KPP Pratama Kuningan secara umum memiliki tingkat kepatuhan wajib pajak, intensitas pemeriksaan pajak, dan penerimaan pajak yang cenderung meningkat setiap semesternya dengan rata-rata masing-masing sebesar $15583,50 \quad$ SPT, 16017,4010 puluhan juta rupiah, dan 59,8960 puluhan juta rupiah.

2. Tingkat kepatuhan wajib pajak dan intensitas pemeriksaan pajak berpengaruh secara simultan dan signifikan terhadap penerimaan pajak pada KPP Pratama Kuningan.

3. Tingkat kepatuhan wajib pajak berpengaruh positif secara signifikan terhadap peningkatan penerimaan pajak pada KPP Pratama Kuningan.

4. Intensitas pemeriksaan pajak berpengaruh positif secara signifikan terhadap penerimaan pajak pada KPP Pratama Kuningan.

5. Intensitas pemeriksaan pajak berpengaruh positif secara signifikan terhadap interaksi tingkat kepatuhan wajib pajak terhadap penerimaan pajak pada KPP Pratama Kuningan.

\section{Saran}

Sesuai dengan kesimpulan yang telah dikemukakan sebelumnya maka dapat disarankan bagi KPP Pratama Kuningan sebagai berikut:
1. Kepatuhan wajib pajak mengalami peningkatan setiap semesternya, untuk lebih meningkatkan kepatuhan wajib pajk secara lebih maksimal maka KPP Pratama Kuningan disarankan agar melakukan kegiatan sosialisasi perpajakan kepada masyarakat khususnya 
wajib pajak secara lebih intensif.

2. Pemeriksaan pajak dan penerimaan pajak mengalami kecenderungan meningkat setiap semesternya, sehingga diharapkan KPP Pratama Kuningan mampu mempertahankan kinerja yang telah dicapai dan lebih meningkatkannya kembali di masa yang akan datang dengan cara menggali potensi wajib pajak yang belum dikelola secara optimal.

3. Tingkat kepatuhan wajib pajak berpengaruh positif dan signifikan terhadap peningkatan penerimaan pajak dimana pengaruhnya akan semakin kuat dengan adanya pemeriksaan pajak. Oleh karena itu, diharapkan pihak KPP Pratama Kuningan mampu mengelola kepatuhan wajib pajak dan pemeriksaan pajak secara lebih maksimal guna menunjang terhadap peningkatan penerimaan pajak.

4. Bagi peneliti selanjutnya yang akan melakukan penelitian dengan tema yang sama, maka sebaiknya menggunakan variabel yang lain dengan metode dan obyek yang berbeda.

\section{DAFTAR PUSTAKA}

Departemen Keuangan dan Badan

Pusat Statistik Republik

Indonesia. 2013.

Realisasi Penerimaan Negara 2007-

2013. Jakarta: Departemen

Keuangan dan Badan Pusat

Statistik RI.

Deviano, Sony dan Rahayu, Siti

Kurnia. 2006. Perpajakan:

Konsep, Teori dan isu. Jakarta:

Kencana.

Ismawan, Indra. 2001. Memahami

Reformasi Perpajakan 2000.
Jakarta: PT Elex Media

Komputindo Kelompok

Gramedia.

Ghozali, Imam. 2011. Analisis

Multivariate dengan Program

SPSS. Semarang: Universitas

Diponegoro.

Rahayu, Siti Kurnia. 2010.

Perpajakan Indonesia: Konsep

dan Aspek Formal.

Yogyakarta: Graha Ilmu.

Sarwono, Jonathan. 2005. SPSS Teori dan Latihan Edisi II. Bandung: PT. Dana Marta Sejahtera Utama.

Sugiyono. 2010. Metode Penelitian Kuantitatif Kualitatif dan $R \& D$. Bandung: Alfabeta.

Undang-Undang Nomor 28 Tahun 2007 tentang Ketentuan Umum dan Tata Cara Perpajakan.

Waluyo dan Ilyas, Wirawan B. 2010. Perpajakan Indonesia. Jakarta: Salemba Empat.

Widodo, Widi. 2010. Moralitas, Budaya dan Kepatuhan Pajak. Bandung: Alfabeta.

Gunadi. 2005. "Fungsi Pemeriksaan Terhadap Peningkatan Kepatuhan Pajak (Tax Compliance)". Jurnal Perpajakan Indonesia Vol 4 : 4-9.

John Hutagaol, Wing Wahyu Winarno, dan Arya Pradipta. 2007. Strategi

Meningkatkan Kepatuhan Wajib Pajak. Akuntabilitas Vol 6: 186-193.

Wonglimpiyarat, Jarunee. 2010. "Economic Innovation Challenges of Financial and Tax Auditing". Journal of Economics and International Finance Vol 2: 290-298. 